KatARZYNa KoŁODZIEJCZYK

Stowarzyszenie Krzewienia Edukacji Finansowej, Gdynia, Polska

The Society for Promotion of Financial Education, Gdynia, Poland

\title{
Gra planszowa „Przedsiębiorczość na planszy” - nowe narzędzie dydaktyczne do edukacji przedsiębiorczej młodzieży
}

\section{Board game „Entrepreneurship on the board” - A new didactic tool for entrepreneurial education of youth}

\begin{abstract}
Streszczenie: Stowarzyszenie Krzewienia Edukacji Finansowej upowszechnia edukację finansową za pomocą inicjatyw edukacyjnych skierowanych do szerokiego grona odbiorców, m.in. nauczycieli przedsiębiorczości, których wspiera w procesie nauczania młodzieży. Odpowiadając na potrzeby nauczycieli w zakresie zwiększenia atrakcyjności i skuteczności nauczania w obszarze podejmowania i prowadzenia działalności gospodarczej, Stowarzyszenie opracowało i udostępniło nauczycielom nieodpłatnie grę planszową „Przedsiębiorczość na planszy”, uzupełnioną konspektami lekcji i przewodnikiem metodycznym (łącznie zwane pakietem „Przedsiębiorczość na planszy). Gra jest dostosowana do warunków szkolnych, a jej tematyka i zakres merytoryczny są zgodne z podstawą programową przedmiotu podstawy przedsiębiorczości. Pakiet „Przedsiębiorczość na planszy” powstał w ramach projektu „Gra na start! Edukacja przedsiębiorcza młodzieży z wykorzystaniem planszowej gry edukacyjnej”, realizowanego przez Stowarzyszenie Krzewienia Edukacji Finansowej z Narodowym Bankiem Polskim w ramach programu edukacji ekonomicznej.
\end{abstract}

\begin{abstract}
The Society for Promotion of Financial Education promotes financial education by undertaking educational initiatives addressed to a wide audience, including teachers of entrepreneurship to support them in the process of teaching young people. Responding to teacher's needs to make teaching about starting and running a business more attractive and effective, the Society has developed and made available to teachers, free of charge, a board game „Entrepreneurship on a board”. The board game is supplemented with lesson outlines and a methodological guide. The game is adjusted to school conditions and its subject matter and content are in line with the core curriculum for the subject Basics of Enterprise. Package „Entrepreneurship on the board” was created for the project „Game to start! Entrepreneurial education of youth with the use of education board game" carried out by the Society for Promotion of Financial Education in cooperation with the National Bank of Poland as part of the Economic Education Program.
\end{abstract}


Słowa kluczowe: edukacja finansowa; edukacja przedsiębiorcza; gra planszowa; konspekty lekcji; podejmowanie i prowadzenie działalności gospodarczej; Stowarzyszenie Krzewienia Edukacji Finansowej

Keywords: board game; entrepreneurial education; financial education; lesson plans; starting and running a business; The Society for Promotion Financial Education

Otrzymano: 15 października 2021

Received: 15 October 2021

Zaakceptowano: 25 listopada 2021

Accepted: 25 November 2021

\section{Sugerowana cytacja/Suggested citation:}

Kołodziejczyk, K. (2021). Gra planszowa „Przedsiębiorczość na planszy” - nowe narzędzie dydaktyczne do edukacji przedsiębiorczej młodzieży. Przedsiębiorczość - Edukacja [Entrepreneurship Education], 17(2), 183-185. https://doi.org/10.24917/20833296.172.13

Stowarzyszenie Krzewienia Edukacji Finansowej (SKEF) od blisko 25 lat popularyzuje edukację finansową wśród różnych grup wiekowych - od dzieci objętych nauczaniem wczesnoszkolnym poprzez młodzież aż do osób dorosłych, w tym seniorów. Podejmowane przez nie inicjatywy edukacyjne, które mają na celu rozbudzenie świadomości, kształtowanie postaw oraz zwiększenie wiedzy z zakresu szeroko pojmowanej edukacji finansowej, mają wymiar praktyczny - pozwalają na bardziej świadome funkcjonowanie w szybko zmieniającym się otoczeniu ekonomiczno-finansowym, kształtują dobre nawyki i wzmacniają kompetencje finansowe w obszarze zarządzania finansami osobistymi.

Istotną grupą objętą wsparciem edukacyjnym Stowarzyszenia są również nauczyciele, zwłaszcza nauczyciele przedmiotu podstawy przedsiębiorczości, z którymi SKEF podejmuje współpracę przy realizacji różnych projektów i działań. Celem SKEF jest ich wsparcie w procesie nauczania przedsiębiorczości: metodyczne, dydaktyczne oraz merytoryczne. W wyniku przeprowadzonych ankiet i wywiadów bezpośrednich z nauczycielami określone zostały ich potrzeby. Za jedną z najważniejszych nauczyciele wskazali brak narzędzi dydaktycznych, które uatrakcyjnią prowadzenie zajęć z młodzieżą z zakresu podejmowania i prowadzenia działalności gospodarczej oraz które byłyby dostosowane do warunków szkolnych i czasu trwania zajęć.

Wychodząc naprzeciw potrzebom nauczycieli, w grudniu 2019 r. SKEF podjęło się realizacji projektu „Gra na start! Edukacja przedsiębiorcza młodzieży z wykorzystaniem planszowej gry edukacyjnej”. Projekt jest realizowany z Narodowym Bankiem Polskim w ramach programu edukacji ekonomicznej. Celem tego działania jest zwiększenie potencjału metodycznego w zakresie nauczania przedsiębiorczości 189 nauczycieli ze szkół ponadpodstawowych w Polsce, dzięki umożliwieniu im swobodnego dostępu i szerokiego wykorzystania nowej (oryginalnej) planszowej gry edukacyjnej wraz z przewodnikiem metodycznym do celów edukacji przedsiębiorczej młodzieży.

Przez blisko półtora roku trwały prace nad opracowaniem gry planszowej „Przedsiębiorczość na planszy”, która w przyjazny i ciekawy sposób pozwoli uczniom na zapoznanie się $\mathrm{z}$ tematyką zarządzania biznesem. Uczniowie wcielają się w rolę przedsiębiorców produkujących i sprzedających sprzęt sportowy. Jako właściciele firm muszą podejmować decyzje dotyczące produkowanego asortymentu, zadbać o zakup odpowiednich zasobów do produkcji, inwestować w rozwój firmy i zatrudniać właściwych specjalistów. Czas 
trwania gry dostosowany jest do warunków szkolnych - rozgrywka podstawowa zajmuje $45 \mathrm{~min}$, zaś wersja rozszerzona - $90 \mathrm{~min}$. Wielkość planszy i pozostałych elementów gry pozwala na swobodne rozgrywki w sali lekcyjnej - są zaprojektowane w taki sposób, aby można je było rozłożyć na ławce/stoliku w klasie. Gra osadzona jest w polskiej rzeczywistości gospodarczej, co ułatwia wyjaśnianie mechanizmów prowadzenia biznesu w Polsce i przekłada się na zwiększenie skuteczności prowadzenia zajęć z zakresu prowadzenia działalności gospodarczej. Tematyka i zakres merytoryczny gry oraz zajęć z jej wykorzystaniem realizowanych na podstawie konspektów opracowanych na potrzeby projektu są zgodne z podstawą programową przedmiotu podstawy przedsiębiorczości.

Prototyp gry był testowany w grupie uczniów szkół ponadpodstawowych podczas zajęć pilotażowych w październiku 2020 r. Gra została oceniona jako ciekawa i wciągająca. Opinie uczniów i nauczycieli posłużyły do opracowania finalnej wersji gry „Przedsiębiorczość na planszy”, która w październiku 2021 r. została przekazana 185 nauczycielom do wykorzystania podczas zajęć w szkole. Oprócz kompletu 6 gier, każdy nauczyciel otrzymał przewodnik metodyczny wraz z konspektami zajęć z zakresu działalności gospodarczej. Przewodnik oraz konspekty są również dostępne do pobrania na stronie projektu (https://www.skef.pl/projekty/projekt-gra-na-start-edukacja-przedsiebiorcza-mlodziezy-z-wykorzystaniem-planszowej-gry-edukacyjnej/). Zgodnie z deklaracjami nauczycieli, w zajęciach z wykorzystaniem gry wzięło udział ponad 8 tys. uczniów szkół ponadpodstawowych z całej Polski.

Od wielu lat jednym z najważniejszych celów polityki Unii Europejskiej jest promowanie nauczania przedsiębiorczości. Projekt „Gra na start! Edukacja przedsiębiorcza młodzieży z wykorzystaniem planszowej gry edukacyjnej” wychodzi naprzeciw tym oczekiwaniom, a nauczycielom ułatwia rozwijanie atrakcyjnych technik dydaktycznych, a także zachęca ich do eksperymentowania. Odwołania do rzeczywistości gospodarczej oraz stworzenie sytuacji „może Ty też kiedyś będziesz przedsiębiorcą” będą, miejmy nadzieję, wzbudzały coraz większe zainteresowanie uczniów szkół ponadpodstawowych zagadnieniami przedsiębiorczości, które będą kształtowały ich kluczowe kompetencje potrzebne w dobie szybkich zmian społeczno-gospodarczych.

Katarzyna Kołodziejczyk, Stowarzyszenie Krzewienia Edukacji Finansowej, kierownik projektu „Gra na strat! Edukacja przedsiębiorcza młodzieży z wykorzystaniem planszowej gry edukacyjnej”, absolwentka Uniwersytetu Jagiellońskiego w Krakowie, ekonomistka, trenerka edukacji finansowej.

Katarzyna Kołodziejczyk, the Society for Promotion of Financial Education, Project Manager of the "Game to start! Entrepreneurial education of youth with the use of education board game", graduate of the Jagiellonian University in Krakow, economist, financial education coach.

\section{Adres/Address:}

Stowarzyszenie Krzewienia Edukacji Finansowej

ul. Legionów 126

81-472 Gdynia, Poland

e-mail: kkolodziejczyk@skef.pl 